\title{
The Goals Programming as a Tool for Measuring the Sustainability of Agricultural Production Chains of Rice
}

\author{
Jesús Silva ${ }^{1}$, Noel Varela ${ }^{2}$, Omar Bonerge Pineda Lezama ${ }^{3}$, David Martínez \\ Sierra $^{4}$, Jainer Enrique Molina Romero ${ }^{5}$, John Anderson Virviescas Peña ${ }^{6}$, and Rubén \\ Dario Munera Ramirez ${ }^{7}$ \\ ${ }^{1}$ Universidad Peruana de Ciencias Aplicadas, Lima, Perú. \\ jesussilvaUPC@gmail.com \\ ${ }^{2}$ Universidad de la Costa, St. 58 \#66, Barranquilla, Atlántico, Colombia \\ nvarela2@cuc.edu.co \\ ${ }^{3}$ Universidad Tecnológica Centroamericana (UNITEC), San Pedro Sula, Honduras \\ omarpineda@unitec.edu \\ ${ }^{4}$ Facultad de Ingeniería Universidad Simón Bolívar, Barranquilla, Colombia. \\ dmartinez@unisimonbolivar.edu.co \\ ${ }^{5}$ Universidad Libre Facultad Ciencia de salud. Barranquilla, Colombia. \\ jainer.molina@unilibre.edu.co \\ ${ }^{6}$ Corporación Universitaria Minuto de Dios- UNIMINUTO. Bello, Antioquia. \\ john.virviescas@uniminuto.edu \\ ${ }^{7}$ Corporación Universitaria Lasallista. Caldas, Antioquia. \\ rumunera@1asallista.edu.co
}

\begin{abstract}
Agricultural activity is characterized by an intensive use of capital and a considerable dependence on external financing. Access to credit is often limited by the scarcity of resources and lack of guarantees, seriously affecting the productivity and economic performance of agricultural exploitations. The objective of this paper is to assess the sustainability of agricultural production chain of rice in Latin America using multi-criteria analysis tools to facilitate decision-making through a benchmarking process to contribute to their economic sustainability. The implementation of the model in an exploitation typy depending on financing sources (conservative, intermediate, and innovative) has revealed the conflict between the goals, being the intermediate exploitation, which gets the best results. The conclusions show that the flexibilization of financing options positively affects the economic performance.
\end{abstract}

Keywords: Agricultural financing; multicriteria programming; Sustainability Rice farming; Decision making; Goals Programming.

\section{Introduction}

The rice in Latin America and the Caribbean (LAC) is a crop of great social and economic importance. Rice consumption in LAC has significantly increased during the last few years, presenting a current average of $30 \mathrm{~kg}$ per person per year. The particularity of the rice produced in LAC lies in its high grain quality, and a 
production that is most often performed under mechanized systems with direct seeding. In LAC, rice is produced under irrigation and rainfed areas in different ecoregions (temperate, tropical moist, tropical dry). Food security and climate change constitute a challenge for rice market in LAC, facing the need to increase production, but stabilizing the yields and the grain quality [1].

The objective of this research is to evaluate the economic sustainability of the agricultural production chain of rice in Latin America through a multicriteria programming model that represents the rice exploitations in Latin America, considering the short-term financing and production. This model will facilitate the formulation of agricultural policies and will serve to reorient the services now provided by institutions. At the same time, the study will allow to deepen in the understanding of real goals of farmworkers and the importance they attach to the different criteria for selecting sources.

\section{Literature Review}

Mathematical programming has been widely used for analyzing financing alternatives in enterprises through financial planning models in the short-term under both certainty [2], and uncertainty conditions [3], [4]. These models consider alternatives such as long-term loans, credit lines, loans postponement, trade credits, and pledge.

In the field of agriculture, for incorporating credit in mathematical programming models, the year is divided into time periods and the circulating capital requirements are added in each of them [5]. If credits are acquired, the interest payments must be added as a cost in the objective function. Alternative financing sources such as traditional lenders, credit unions, or banks can be added as separate activities and it is possible to integrate restrictions on credit limitations by source type [6], [7].

When several objectives must be integrated, including qualitative data, the multicriteria programming can be used. This technique assumes that economic agents seek to find a balance or compromise between a set of objectives, usually in conflict [8], [9]. The commonly used methodologies for solving this issue are the restrictions method, the weighting method, and the goals and commitments programming method [10].

The financial management of agricultural exploitations has been presented by models that use the multicriteria analysis and its different resolution methods, integrating objectives related to agricultural planning [11], which consider the objective of indebtedness minimization. The following researches are the basis for the development of this study [12], [13], [14].

\section{Method}

The research was developed in three phases, according to [15], [16], [17]. The first of them consisted of a documentary monographic research on the statistical information about the risk sources in rice production, mainly about the interest rate, inflation, and the financial problems, among others. 
The second one consisted of a study of the reality of a sample of the rice farmers in 5 Latin American countries, among them: Brazil, Cuba, Colombia, Venezuela, and Uruguay. A population of 1648 producers was considered, from which a sample was extracted by means of stratified random sampling. For this purpose, the sample was divided into 6 strata (from 1 to 50 hectares, from 51 to 100 hectares, from 101 to 150 hectares, from 151 to 200 hectares, from 201 to 500 hectares, and greater than 500 hectares).

Finally, the sample was constituted by 160 producers. An optimal allocation was made, which is the distribution method for a given sample size in $\mathrm{n}$ units since it produces more accurate results [10], [11], thus constituting the strata. The producers were randomly selected by the method of random numbers [6].

In order to characterize these producers, a technical survey was applied and 18 of the qualified entities of the Latin American financial institutions were interviewed, applying both instruments at the end of 2018 .

Additionally, interviews were conducted with experts in the field of rice financing and cultivation. Given the limitation to apply the model to each exploitation, a typology was made of the exploitations under study, based on the characteristics of an innovative producer in relation with its financial decisions [15]. The variables considered were diversification of the number of sources, dominance of economic criteria over personal criteria, lower total cost per hectare, lower financial cost, lower percentage of external financing, desire to explore other sources, and higher performance [16].

These variables were entered into the Statgraphics plus 5 software to establish the cluster, using the maximum distance method (Furthest Neighbor) and the Squared Euclidean distance measure [18].

The third phase centered on the design of a multicriteria programming model that represents the economic operation of the exploitations in the typology, using the average of the explotations as data from each group. The model is mathematically presented in Gams language and developed through non-linear programming, adding some scenarios to see the behavior of the model against some changes in its variables [11], [12].

\section{Results and Analysis}

\subsection{Presentation of the area under study and survey results.}

The results of the surveys applied to rice producers in the Latin American sample show that the most important general problems were the limitations of small producers to access private credits, high dependence on production with external financing, and scarcity of medium and long-term credits. The benefits of the crops are highly influenced by inflation, the exchange rate, the State price fixing, and the political conditions at the time of the survey.

In rice production, there is a horizontal integration between producers and between financing sources, as well as vertical integration between the producer and the sources through the harvest; scarce problems of asymmetric information, differences in credit 
conditions in relation to interest rates, granted amounts, time of granting, closeness to the client, technical assistance, and responsibility, among other features. The most used criteria for choosing the source by the part of the producers were: the opportunity (referred to the granting of credit in the required time), interest rate, amount, client, trust, input availability, technical assistance, deadline, organization, and proximity.

The most used financing institutions were the associations, followed by the commercial houses, banks, public institutions, and the agroindustries.

\subsection{Farmers Typology.}

Three groups were formed: innovative, conservative, and intermediate exploitation depending from their attitude toward financing [19]. The results are shown in Table 1.

Table 1. Results of the cluster and centroids

\begin{tabular}{lllllllllll}
\hline Cluster & $\begin{array}{l}\mathbf{N}^{\mathbf{0}} \text { of } \\
\text { producers }\end{array}$ & $\mathbf{\%}$ & NS & OPP & CLI & TC & FC & FFX & CA & RY \\
\hline $\mathbf{1}$ & 87 & 54.38 & 1.85 & 0.92 & 0.71 & 1.2342 & 0.1023 & 61 & 0.62 & $\mathbf{5 . 1 0 2}$ \\
2 & 43 & 26.88 & 1.95 & 0.832 & 0.12 & 1.5821 & 0.115 & 60.2 & 0.93 & 5.839 \\
$\mathbf{3}$ & $\mathbf{3 0}$ & $\mathbf{1 8 . 7 5}$ & $\mathbf{0 . 7 9 5}$ & $\mathbf{0 . 4 2}$ & $\mathbf{0}$ & $\mathbf{1 . 1 0 2 5}$ & $\mathbf{0 . 0 4 5 2}$ & $\mathbf{3 2}$ & $\mathbf{0 . 7}$ & $\mathbf{4 . 9 3}$ \\
\hline
\end{tabular}

NS: number of sources, OPP: opportunity; CLI: client; TC: total cost; FC: financing cost; FFX: foreign financing percentage; $\mathrm{CA}$ : desire to explore other forms of financing; $\mathrm{RY}$ : rice yield $(\mathrm{kg} / \mathrm{ha})$.

\subsubsection{Intermediate Exploitation}

This type presents average values with respect to the other groups in variables such as yields, income, financial cost for interest payments, profit, depreciation, and total cost. About the criteria for choosing the financing source, they give more value to trust, being a client of the financial institution, opportunity, and interest. By having these first two values higher than the rest of the types, it can be said that they give an important weight to personal criteria and are not interested in exploring new sources. On the other hand, this group includes those farmworkers who sow in a staggered way and diversify the sources. It can be concluded that, from a technical point of view, they are innovative or have no limitations to carry out a greater number of sowing but are more reluctant to explore new sources.

\subsubsection{Innovative Exploitation}

In this group, the income is greater but the variable costs, financing costs, benefit, and the depreciation are also higher. For this type, the most important criteria are opportunity, amount, technical assistance, and interest, prevailing the economic criterion. They also value the shared risk by preferring technical assistance. In addition, the data suggest an open disposition to innovations. 


\subsubsection{Conservative Exploitation}

This type presents low returns, income, total cost, benefit, and average depreciation. Interests are more important than the opportunity and show low values in relation to the other criteria. In relation to the ratios, this group shows the greatest relationships, so it can be said that they are efficient from an economic point of view.

\subsection{Design of the Optimization Model}

The fundamental features of the model can be summarized as follows: descriptive, with qualitative and quantitative variables; economic-productive, integrating linear and non-linear functions; in the short term, with random elements and multiple objectives which include the criteria for choosing farmworkers with respect to their financing source.

For the model, the following assumptions are assumed [15]: the alternative activities are the financing sources; the introduction of other crops or technologies is not proposed; only rice production with two crops per year is considered; the same variety of rice is used, and with the same price. The producer is solvent and has the necessary guarantees to take loans, no agricultural insurance is taken, and pays the established interest; there are no additional charges for technical assistance, insurance, or contingency funds. The credit restrictions are taken according to the information provided by the financial sources; credits are requested at the beginning of the sowing and are paid at the end.

Following is the programming model used to optimize the sample through algorithms 1 and 2, following the model of [21]:

Algorithm 1. Optimize objectives and agronomic constraints

1) Objective - profit maximization in thousands of dollars:

$$
Z=\left(\sum_{p}^{12}\left(I T_{p}-C V T_{p}-C f i j_{p}\right)\right)-C F T
$$

2) Objective - satisfaction of producer's preferences regarding the financing source:

$$
W=\sum_{f=1}^{12} \sum_{s=1}^{12}\left(E f_{f} * X_{f_{s}}\right)
$$

3) Objective - risk minimization:

$$
V=\frac{1}{n} \sum_{n=1}^{7}\left(Z N_{n}-Z\right)^{2}
$$

Subject to:

Restrictions on surface occupation per period: 


$$
\sum_{s=1}^{12} u \operatorname{SOSu_{sp}}{ }^{*} N H A_{s} \leq d \sup
$$

Restrictions on occupation of the total area per planting:

$$
\sum_{s=1}^{12} N H A_{s}=2 * d \text { sup }
$$

Equation of Random Benefit Calculation:

$$
Z N_{n}=\left(\sum_{s=1}^{12} \sum_{p=1}^{12}\left(r e n \eta^{*} p r_{p n}\right) * N H A s\right)-\left(\sum_{p=1}^{12}(C V T+C f i j)\right)-\left(\sum_{f=1}^{5} \sum_{s=1}^{12} \sum_{p=1}^{12}\left(V_{p s} * X_{f s}^{*} t i_{f n} * v u_{s}\right)\right)
$$

Where:

Z: total exploitation benefit; ITp: total income; CVTp: total variable cost; Cfijp: fixed cost per period; CFT: total financial cost and p: period; W: measure that establishes the order of the financing sources according to the producer's preferences; Eff: distance L1 from the weight of the score provided by the producers to each criterion by rating of each standardized source; Xfs: amount of credit requested by source; V: benefit variance; ZNn: benefit in each state of nature (n); usosusp: period of time in which each planting of rice occupies the soil surface; NHAs: surface to be sown; dsup: maximum surface availability in hectares; rens: rice yields in $\mathrm{kg} / \mathrm{ha}$ per planting; prpn: sale price of rice production for each state of nature (thousands US\$ $/ \mathrm{kg}$ ); Vsps: month of the production's sale; vus: credit useful life corresponding to months (periods); and tifn: monthly interest rate for each state of nature.

Algorithm 2. Financial restrictions

Restrictions on the total amount of credit to be requested by planting:

$$
\sum_{f=1}^{12} X_{f s}<C V T_{p}
$$

Restrictions of maximum amount granted by financing source:

$$
X_{f s} \leq m f_{f} * d \sup
$$

Financial cost per period:

$$
C F p_{p}=\left(\sum_{f=1} \sum_{s=1} V S_{s p}{ }^{*} X_{f s}\right) *\left(t r_{f}{ }^{*} V u_{s}\right)
$$

Credit payment per period:

$$
A M O R_{p}=\left(\sum_{f=1}^{12} \sum_{s=1}^{12} V S_{s p} * X_{f s}\right) *\left(1+\left(t r_{f}^{*} V u_{s}\right)\right)
$$

Total financial cost: 


$$
C F T=\sum_{p=1}^{12} C F p_{p}
$$

General Balance per period:

$$
\left(\sum_{f=1}^{12} \sum_{s=1}^{12} X_{f s}{ }^{*} i s_{s p}\right)+l i q 0_{p}+L I Q_{(p-1)}+I T_{p}=C V T_{p}+C O N S_{p}+L I Q_{p}+A M O R_{p}+C f i j_{p}
$$

Short-term financial balance equation per period:

$$
\left(\sum_{f=1}^{5} \sum_{s=1}^{12} X_{f s} *^{i S_{s p}}\right)+l i q 0_{p}+L I Q_{(p-1)} \geq C V T_{p}
$$

Restrictions on the amounts covered by financing sources, planting, and period: In the case of financing by agrocommerce.

$$
X_{\text {agrocomercio, } s} \leq C V L_{s, c \text { mprod }, p}+C V L_{s, c p p r o d, p}+C V L_{s, f p r o d, p}+C V L_{s, p p r o d, p}
$$

In the case of financing by agroindustry.

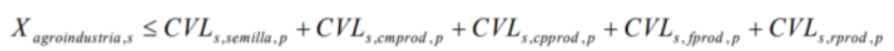

Where:

Xfs: amount of credit that is requested by source and by seeding; CVTp: total variable cost; mff: amount to be financed by the source (thousands of US\$/ha); Vssp: month of the production sale in each sowing; trf: interest rate per period for each source monthly percentage; Vus: useful life of the credit which corresponds to the months (periods) between the granting and its payment; CFpp: financial cost period, liq0p: initial liquidity per planting; LIQp-1: liquidity of the previous period; ITp: total income; CVTp: total variable cost; CONSp: monthly family consumption; LIQp: liquidity of the period; AMORp: payment of the credit; Cfijp: fixed cost, Xagrocomercio,s: amount of credit that is requested to the agrocommerce; Cvlslp: variable cost per task; cmprod: cost per products for weed control; cpprod: cost per products for pest control; fprod: cost per products for fertilization; rprod: cost per products for the reboot; Xagroindustria,s: amount of credit requested by the agroindustry; and, CVLs,semilla,p: variable costs by seed purchase for planting rice.

As the exclusive means of external financing used by producers is credit, the alternatives presented correspond to the existing sources of credit. Five types of institutions are established (banking, association, public, agrocommerce, and agroindustry), while the data assumed for the model is calculated using the average or the mode of the characteristics in the eighteen surveyed sources.

The objectives are [21]: maximize the benefit $(\max Z)$, satisfaction of the producer's preferences with respect to the financing source (min W) and minimize the risk ( $\min \mathrm{V})$. These objectives contribute equal weight. The objective of $\min \mathrm{W}$ is used as an ordinal condition (a fictitious objective) to establish a measure that reflects the order of funding sources, according to the producer's preferences. For this 
purpose, the amounts of credits to be requested are used, multiplied by the weight attributed by the producer to each chosen source according to their criteria. Therefore, the smaller its value (minimization), the closer it is to the observed producer's preferences with respect to its financing source.

The procedure for converting the qualitative selection criteria into quantitative variables was as follows [1]: identification of opinions related to financing sources, quantification of the attribute according to the number of producers who vote for each of them, introduction of the distance between the assigned values and the ideal value. Each choice or non-dominated alternative is considered an efficient endpoint. Calculation of the distances between each alternative or efficient endpoint with respect to the ideal point, for the $\mathrm{L} 1$ metric.

The model incorporates the risk in the cultivation of rice, which is affected by some variables, including climatology (rainfall), productivity (attack of weeds and pests), economy by the change in price of the product, and financial variables by the variation of the credit interest rate. In the model, the risk is measured by means of the variance in benefit, integrating the variation of the interest rate (as a financial risk) and the price of the rice (as business risk) using its historical series of the last seven years. The producer can improve its financing if its management and productive processes are improved. Therefore, several scenarios and sensitivity analyses were considered, as follows [14], [21]:

Scenario E1: Base Model. The multi-objective model of exploitation described above is considered.

Scenario E2: Credits per Periods. A credit modality is introduced in the base model in which the producer can have the credit in the month it needs it and pays interests according to the months elapsed from its granting to the payment date. The difference of this type of credit, given by items, is that the interest rate is the same as at the beginning of the sowing when it was requested. However, in this case, the period for calculating the loan payment and interests will be that of the months that elapsed from the withdrawn until the payment date.

Scenario E3: Stepped Planting. It integrates the possibility of selecting up to twelve plantings of rice per year, one for each month. The stepped planting is recommended by technicians of the zon, because it generates a periodicity in the income that will favor the producer and diminishes the foreign financing requirements. It is achieved by making time periods in a circular way where the planting number thirteen (s13) becomes the first planting (s1) again.

Sensitivity Analysis: new prices are introduced so that two possibilities are appraised, namely: a 10\% increase in prices, which should improve the results in the base model and a price decrease by $10 \%$. In this way, the sensitivity of the base model to this change was identified.

\subsection{Results of the Model}

For the resolution of the base model, it is assumed that the exploitation is cultivated in its entirety, for all eploitations, in both sowings (summer and winter). This is introduced to achieve that the analysis of the selection behavior about the amounts and financing sources are comparable in the three objectives [13]. The model 
calculates total revenues and costs according to the financial cost generated by the interest accrued by the credits requested from the financing source, considered as optimal by the model (Table 2).

Table 2. Economic calculations of the Base Model for profit maximization

\begin{tabular}{lllll}
\hline Exploitation & Income & Costs & $\begin{array}{l}\text { Costs } \\
\text { Financial }\end{array}$ & Benefit \\
\hline Intermediate & 3.068952346 & 2.196523741 & 0.092 & 0.957 \\
Innovative & 3.41256327 & 2.423058941 & 0.132 & 0.899 \\
Conservative & 2.895742385 & 2.0005211 & 0.093 & 0.735 \\
\hline
\end{tabular}

The payment matrix of the base model objectives is presented in Table 3 . In this matrix, the conflict that represents the variation between the ideal (in bold) and the anti-ideal (underlined) between the objectives when max $\mathrm{Z}$, for the INTERMEDIA exploitation is $31.7 \%$ and $\min \mathrm{W}$ represents $120,15 \%$; however, in $\operatorname{minV}$, the conflict is $18.41 \%$. In the case of INNOVATIVE exploitation, max Z presents a conflict of $33.23 \%$. On the other hand, min $\mathrm{W}$ of $170.01 \%$, and the risk of $18.52 \%$. However, the CONSERVATIVE exploitation presents a conflict of $40.03 \%$ in profits, higher than the rest of the holdings, while for the case of $\min \mathrm{W}$, it presents a lower conflict than the rest of $64.29 \%$, and $18.03 \%$ for $\min \mathrm{V}$.

Table 3. Payments Matrix of the Base Model

\begin{tabular}{lcccc}
\hline Exploitation & FO & $\begin{array}{c}\text { Z (thousands of } \\
\text { S US) }\end{array}$ & W & V \\
\hline Intermediate & Max Z & $\mathbf{7 2 . 5 4 2}$ & $\underline{5,754.32}$ & $\underline{\mathbf{2 , 6 8 2 . 1 0}}$ \\
& Min W & 59.98 & $\mathbf{2 , 5 1 2 . 4 2}$ & $\mathbf{2 , 4 1 0 . 1 5}$ \\
& Min V & $\underline{55.242}$ & $4,341.23$ & $\mathbf{2 , 2 9 9 . 4 2}$ \\
Innovative & & & & \\
& Max Z & $\mathbf{4 5 . 5 2 4}$ & $\underline{5,252.13}$ & $\underline{\mathbf{1 , 6 1 5 . 1 2}}$ \\
& Min W & 34.899 & $\mathbf{1 , 8 5 2 . 1 0}$ & $\mathbf{1 , 4 4 2 . 1 2}$ \\
& Min V & $\underline{34.312}$ & $3,754.44$ & $\mathbf{1 , 4 1 2 . 2 5}$ \\
& & & & \\
Conservative & Max Z & $\mathbf{7 9 . 0 1 5}$ & $5,098.91$ & $\underline{\mathbf{3 , 8 5 2 . 1 2}}$ \\
& Min W & $\mathbf{7 8 . 9 9 8}$ & $\mathbf{4 , 7 8 5 . 1 4}$ & $\mathbf{3 , 8 5 1 . 4 1}$ \\
& Min V & $\underline{\mathbf{5 6 . 7 2 5}}$ & $\underline{\mathbf{7 , 9 9 5 . 7 3}}$ & $\mathbf{3 , 7 5 1 . 1 0}$ \\
\hline
\end{tabular}

Despite the little conflict manifested in the minimization of risk, its integration into the model introduces changes in the source selection since risk is a fundamental element in the granting of a loan. The low conflict is since the variation of the interest rate affects the financial cost, which is a part of the total costs. Therefore, its magnitude is small in relation to the random benefits. Starting from the payment matrix, the extreme points closest to the ideal were obtained through the programming goals. The goal set was calculated, which defines the restricted efficient set to obtain efficient solutions of $\max \mathrm{Z}, \min \mathrm{W}$, and $\min \mathrm{V}$ together. In relation to the benefit, the target solution per hectare shown in Table 4 is between 0.795 to 0.802 thousand US\$/ha for the INTERMEDIATE operation, at 0.707 US\$/ha for the INNOVATIVE, and between 0.761 and $0.710 \mathrm{US} \$ /$ ha for the CONSERVATIVE; therefore, it is 
higher in the INTERMEDIA exploitation.

Table 4. Results for L1 and L? in the Base Model

\begin{tabular}{llll}
\hline $\begin{array}{l}\text { Metric and } \\
\text { exploitation }\end{array}$ & $\begin{array}{l}\mathbf{Z} \\
\text { (thousands } \\
\text { of US\$) }\end{array}$ & $\mathbf{W}$ & $\mathbf{V}$ \\
\hline Metric L1 & & & \\
$\begin{array}{l}\text { Intermediate } \\
\text { Innovative }\end{array}$ & 60,042 & $2,595.46$ & $\mathbf{2 , 4 8 1 . 2 2}$ \\
Conservative & 36,508 & $1,966.61$ & $\mathbf{1 , 4 0 5 . 1 2}$ \\
Metric L? & 76,568 & $4,891.05$ & $\mathbf{3 , 8 1 4 . 2 9}$ \\
$\begin{array}{l}\text { Intermediate } \\
\text { Innovative }\end{array}$ & 60,591 & $2,668.39$ & $\mathbf{2 , 4 6 4 . 8 7}$ \\
Conservative & 36,508 & $1,966.61$ & $\mathbf{1 , 4 0 5 . 1 2}$ \\
\hline
\end{tabular}

L1: distance one. L?: infinite distance

Figure 1 compares the choice of financing source between the producers and the Base Model for the different objectives.

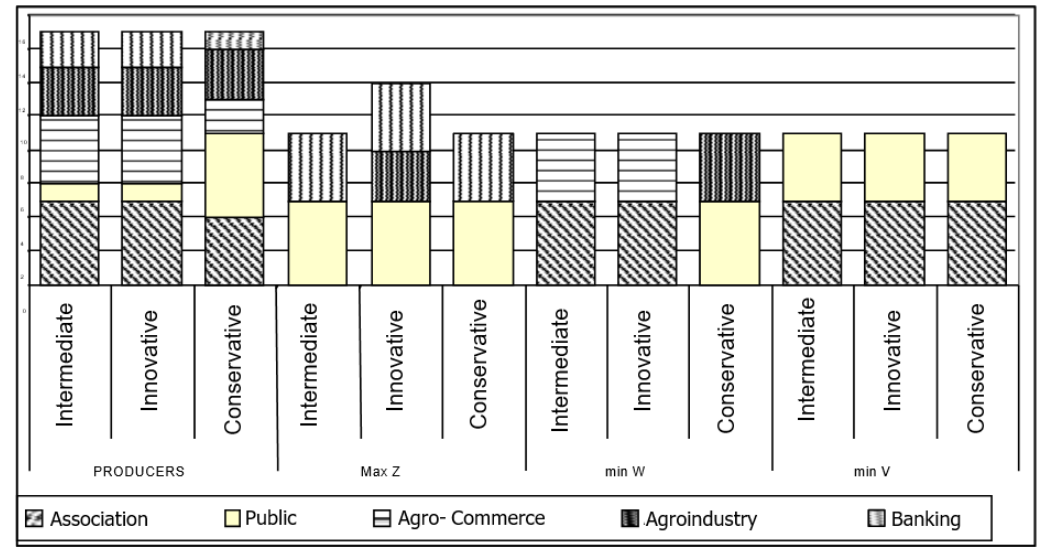

Fig 1. Comparison of the choice of financing source between producers and the Base Model for the different objectives.

When observing the financing sources chosen in the base model by objective (Figure 1) where the thickest color strip is the first choice and the last one is the thinnest, it means that for the max Z, the INTERMEDIA exploitation first chooses the public source and then banking. For INNOVADORA, the order will be public, banking, and agroindustry; for the CONSERVATIVE, it will be public and banking, for min $\mathrm{W}$, the INTERMEDIA and INNOVATIVE exploitations use the association and agro-commerce source, while the CONSERVATIVE chooses the public sources and agroindustry.

In the objective min $\mathrm{V}$, they use association and public. The model reproduces the producer's behavior in the second objective when it establishes the satisfaction of the producer's preferences with respect to the financing source, except in the case of the 
CONSERVATIVE, which uses agrocommerce in the second place instead of the association, as happens with the producers.

\section{Conclusions}

The studied producers give great value to their criteria for choosing the financing source, including the opportunity (credit granting time) and shared risk (evidenced through the criteria of being a client, technical assistance, and trust with the source). Not always the most innovative producers obtain greater benefits with respect to financing, probably because they are not looking for better financial opportunities. The resulting alternatives privilege the public source and the banks in the maximization of benefits. The same occurs with the association and agrocommerce source in the satisfaction of preferences, and with the association and public source in the risk minimizing.

The model shows results that positively respond to an increase in profits when the price increase is introduced, the stepped planting, the credit per period and, negatively, to the decrease in prices. The benefits are highly affected by price variations. As the analyzed scenarios and variations can be used together, it is expected that a producer who obtains periodic credits and staggers in a price increase, reaches the maximum benefit. When facing a price reduction, producers of the conservative type have a lower impact on the reduction of benefits.

\section{References}

1. Rebolledo, M.C., Ramirez-Villegas, J., Graterol-Matute, E., Hernández-Varela, C.A., Rodríguez-Espinoza, J., Petro-Páez, E.E., Pinzon, S., Heinemann, A., Rodríguez-Baide, J.M., Van Den, B.M.: Modelación del arroz en Latinoamérica: Estado del arte y base de datos para parametrización. Luxembourg: Publications Office of the European Union (2018).

2. Carrijo, D. R., Lundy, M. E., Linquist, B. A.: Rice yields and water use under alternate wetting and drying irrigation: a meta-analysis. Field Crops Research 203 (1), 173-180 (2017).

3. Pérez, M. P., Cortiza, M. A. P.: Los rendimientos arroceros en Cuba: propuesta de un sistema de acciones. Revista Economía y Desarrollo (Impresa) 152(2), 138-154 (2016).

4. Lezama, O. B. P., Izquierdo, N. V., Fernández, D. P., Dorta, R. L. G., Viloria, A., Marín, L. R.: Models of Multivariate Regression for Labor Accidents in Different Production Sectors: Comparative Study. In International Conference on Data Mining and Big Data, Springer, Cham, 10942 (1), 43-52 (2018).

5. Suárez, J. A., Beatón, P. A., Escalona, R. F., Montero, O. P.: Energy, environment and development in Cuba. Renewable and Sustainable Energy Reviews, 16(5), 2724-2731 (2012).

6. Sala, S., Ciuffo, B., Nijkamp, P.: A systemic framework for sustainability assessment. Ecological Economics 119 (1), 314-325 (2015).

7. Singh, R. K., Murty, H. R., Gupta, S. K., Dikshit, A. K.: An overview of sustainability assessment methodologies. Ecological indicators 9(2), 189-212 (2009).

8. Varela, N., Fernandez, D., Pineda, O., Viloria, A.: Selection of the best regression model to 
explain the variables that influence labor accident case electrical company. Journal of Engineering and Applied Sciences 12 (1), 2956-2962 (2017).

9. Yao, Z., Zheng, X., Liu, C., Lin, S., Zuo, Q., Butterbach-Bahl, K.: Improving rice production sustainability by reducing water demand and greenhouse gas emissions with biodegradable films. Scientific reports 7 (1), 1-12 (2017).

10.Suárez, D. F. P., Román, R. M. S.: Consumo de água em arroz irrigado por inundação em sistema de multiplas entradas. IRRIGA 1(1), 78-95 (2016).

11.Stuart, A. M., Pame, A. R. P., Vithoonjit, D., Viriyangkura, L., Pithuncharurnlap, J., Meesang, N., Lampayan, R. M.: The application of best management practices increases the profitability and sustainability of rice farming in the central plains of Thailand. Field Crops Research 220 (1), 78-87 (2018).

12.Aprianti, E., Shafigh, P., Bahri, S., Farahani, J. N.: Supplementary cementitious materials origin from agricultural wastes-A review. Construction and Building Materials 74 (1), 176187 (2015).

13.Gomes, A. D. S., Scivittaro, W. B., Petrini, J. A., Ferreira, L. H. G.: A água: distribuição, regulamentação e uso na agricultura, com enfase ao arroz irrigado. EMBRAPA Clima Temperado-Documentos (INFOTECA-E) (2018).

14.Donkor, E., Owusu, V.: Effects of land tenure systems on resource-use productivity and efficiency in Ghana's rice industry. African Journal of Agricultural and Resource Economics 9(4), 286-299 (2014).

15.Baloch, M. A., Thapa, G. B.: The effect of agricultural extension services: Date farmers' case in Balochistan, Pakistan. Journal of the Saudi Society of Agricultural Sciences 17(3), 282-289 (2018).

16.Izquierdo N.V., Lezama O.B.P., Dorta R.G., Viloria A., Deras I., Hernández-Fernández L.: Fuzzy Logic Applied to the Performance Evaluation. Honduran Coffee Sector Case. In: Tan Y., Shi Y., Tang Q. (eds) Advances in Swarm Intelligence. ICSI 2018. Lecture Notes in Computer Science, Springer Cham 10942 (1), 1-12 (2018).

17.Bezerra, B. G.; Da Silva, B. B., Bezerra, J. R. C., Brandão, Z. N.: Evapotranspiração real obtida através da relação entre o coeficiente dual de cultura da FAO-56 e o NDVI. Revista Brasileira de Meteorologia 25 (3), 404 - 414 (2010).

18.Diaz-Balteiro, L., González-Pachón, J., Romero, C.: Forest management with multiple criteria and multiple stakeholders: An application to two public forests in Spain. Scandinavian Journal of Forest Research 24(1), 87-93 (2009).

19.Hák, T., Janoušková, S., Moldan, B.: Sustainable Development Goals: A need for relevant indicators. Ecological Indicators 60 (1), 565-573 (2016).

20.Lampayan, R. M., Rejesus, R. M., Singleton, G. R., Bouman, B. A.: Adoption and economics of alternate wetting and drying water management for irrigated lowland rice. Field Crops Research 170 (1), 95-108 (2015).

21.Delgado. A., Blanco, F. M.: Modelo Multicriterio Para El Análisis De Alternativas De Financiamiento De Productores De Arroz En El Estado Portuguesa, Venezuela. AGROALIMENTARIA 28 (1), 35-48 (2009). 